\title{
Halal Label vs Product Quality in Halal Cosmetic Purchasing Decisions
}

\section{Grisna Anggadwita ${ }^{\mathrm{I}}$, DiniTuripanam Alamanda ${ }^{2}$, and Veland Ramadani ${ }^{3}$}

School of Economics and Business, Telkom University ${ }^{\mathrm{I}}$, Faculty of Economics, Garut University ${ }^{2}$, Faculty of Business and Economics, South-East European University, Republic of Macedonia $^{3}$

\author{
grisnamailbox@yahoo.co.id ${ }^{I}$ \\ alamanda.dini.20I7@gmail.com² \\ v.ramadani@seeu.edu.mk
}

\begin{abstract}
This study aims to analyze customer purchasing decisions on cosmetic products by considering halal labels or product quality where brand image is an intervening variable. This study uses quantitative methods with confirmatory objectives. Questionnaires are distributed using a purposive sampling method for 400 respondents in several villages throughout Indonesia. The results showed that the halal label significantly influenced brand image and purchasing decisions.Product quality affects brand image but has no impact on purchasing decisions. Meanwhile, brand image has a significant influence on purchasing decisions. The research implications show that for rural communities, promotion of halal cosmetics is more useful for driving purchasing decisions compared to the quality of cosmetic products.
\end{abstract}

Keywords: Halal cosmetic, halal certification, product quality, promotion strategy, purchasing decision

\section{A. INTRODUCTION}

The cosmetics industry is one of the largest consumer sectors in Indonesia. On the other hand, the halal lifestyle is seen as a new lifestyle for the Muslim population in the world, especially the Muslim in Indonesia (Adinugraha \& Sartika, 2019). The concept of halal or Islamic is traditionally understood to be applied to food products and banking \& financial services but later developed into other product categories, including cosmetics (Islam \& Chandrasekaran, 2013). In 20I4, the global Muslim cosmetics industry spent $\$ 54$ billion, or around $7 \%$ of world spending, and will increase by 2020 by $\$ 80$ billion (Yuswati, 2018). The cosmetics industry in Indonesia recorded an increase in growth in 2018 from the previous year of $20 \%$ which was triggered by huge demand from the domestic and export markets, especially for women who are the main target of the cosmetics industry (Ministry of Industry, 2018). In Asia-Pacific, China and India, high demand occurred in color cosmetics for the period 2015-2020. Color 
cosmetics are dyes and cosmetics used in eye shadow, foundation, nail polish, lipstick, and others (Mohammadzadeh, 2015).

Halal cosmetics are considered an innovation in the cosmetics industry, because they introduce new and different internal and external operations that can serve customer demands (Mohezar, Zailani, \& Zainuddin, 2016). Until in 2010, Wardah emerged by proclaiming it as the pioneer of the first halal labeled cosmetics in Indonesia, which was then followed by several predecessors such as Mustika Ratu and Sariayu. Cosmetic products from the Wardah Brand use halal certification as a key selling point to address the aspirations of beauty and preferences of Muslim women.

Despite the potential of this industry, many consumers are unaware of the importance of the halal brand, with a relatively low response rate to halal cosmetic products (Rajagopal, Ramanan, Visvanathan, \& Satapathy, 20II). Halal awareness is influenced by several factors such as halal knowledge by frequently following the halal development or halal exhibition events, halal training, and the halal certification process (Nusran, Gunawan, Razak, Numba, \& Wekke, 2018). Halal awareness among consumers, quality certification of halal products, and market promotion positively influences one's customer's purchase intentions on halal products (Hussin, Hashim, Yusof, \& Alias, 2013; Majid, Sabir, \& Ashraf, 2015).

Cosmetics companies and brands are considered as the main determinants of the development of the halal cosmetics market for Muslim women (Majid et al., 2015). However, Hussin, Hashim, Yusof, \& Alias (2013) added that consumer behavior in buying halal products considers the five factors of product brand, price, quality, ingredients and labels. Based on the results of a study fromLutfie, Suzanti, Omar Sharif, \& Alamanda (2016) found that the halal label was able to improve the Wardah brand image as a cosmetic product aimed at Muslim women, but had not been able to significantly influence consumers in their purchasing decisions. Product quality is the driving factor for consumers in buying their cosmetics. This finding is supported by Rauschnabel, Herz, Schlegelmilch, \& Ivens (2015) showed that the perception of halal labels on packaging, attitudes towards religion and brands, while the relative importance of the two antecedents depends on several consumer characteristics.

The purpose of this study is to analyze several variables that are indicated to be able to influence customers in buying halal cosmetic products. This study confirms the findings of Hussin et al. (2013); Majid et al. (2015); Lutfie et al. (2016) regarding how product quality, halal labels(Hasibuan, Dharma, Putra, \& Anggraini, 2017) related to purchasing decisions. In more detail, also discussed 
the effect of halal labels on brand image (Lutfie et al. 2016), brand image has a significant effect on intentions to buy cosmetics (Eze, Tan, \& Yeo, 20I2).

\section{B. THEORITICAL}

\section{Consumer Behaviour}

Anjana(2018)analyzed that consumers use cosmetic products to clean, physically change their appearance to make them look attractive. In line with these findings that women use cosmetics to be fresher and more beautiful, for skin health, better moods, to improve self-confidence and appearance especially at work or other public places where they are more often seen(Joelle, Sudarmiatin, \& Hermawan, 2017).

Women's perspective on cosmetic products is now getting better and more innovative. Many women try different kinds of cosmetics at different price levels to get cosmetics that are suitable for the skin and the look they want(Joelle et al., 20I7).The findings of Zhang \& Zhou (2019) said that consumer behavior in purchasing cosmetics is very uncertain and changing, one of which is the lack of product knowledge which is a factor that causes such inconsistencies.

Kumar, John, \& Senith (20I4) said that the level of income affects the desires or opinions of groups and affects consumer behavior in purchasing cosmetics. Whereas for, Khan, Karim, \& Abbas (2016) gave rise to findings that the metrosexual role influences their behavior in buying cosmetics.Kumar et al. (20I4) also added that cultural factors influence young people in purchasing cosmetics, for example in the campus and work environment. In addition, celebrity and influencer factors also often influence young women in purchasing behavior of the type and brand of cosmetics used.In contrast to Anjana's findings (2018), there are five factors that influence consumer decisions in buying cosmetic products, namely product quality, product prices, brand names, product packaging and advertisements.

\section{Halal Label}

Halal cosmetics are products, which are sourced from halal materials and are produced in accordance with the halal system, which is used for certain body parts for the purpose of beautifying, cleaning, protecting, and changing the appearance of the body (Sugibayashi et al., 2019). Halal certificates play an important role to convince consumers that the product has obtained the necessary conditions from halal products (Hanzaee \& Ramezani, 20II). Legal aspects of trade / sales are needed in protecting all its citizens, while Halal Products assurance is an effort to protect Muslim consumers in the consumption of goods and or services 
(Hamzah, Ayodahya, \& Haque, 2019). Several previous studies have discussed the relevance of halal labels on cosmetics purchases, especially in countries that label themselves as Global Halal Hub (ASEAN countries) (Sa'id, 20I2). In Indonesia, research on halal cosmetics has been done byEndah (20I4); Noor (20I5); Briliana \& Noviana (2016); Lutfie et al. (20I6); Aisyah (20I6); MarkPlusinc (2016); I. S. Putri, Daryanti, \& Ningtias (2019); T. U. Putri \& Abdinagoro (2018). Lutfie et al. (2016)said that there is a halal label influence on the brand image of cosmetic products and on consumer purchasing decisions. The statement was supported byHasibuan et al. (2017).

$\mathrm{H}_{\mathrm{I}}$ : There is a direct influence of halal labels on brand image

$\mathrm{H}_{2}$ : There is a direct influence of halal labels on purchasing decisions

\section{Product Quality}

Cosmetic products usually consist of a mixture of complex chemical formulations that are used on certain parts of the human body to enhance external appearance or provide protection against environmental challenges such as UV radiation (Salvador \& Chisvert, 2007). Vinardell \& Mitjans (2017) explained that good cosmetic products are those that do not use animals in the testing process although they are still worrying in terms of the composition of substances that are harmful to human health such as dyes, preservatives, UV-filters, and nanomaterials.

Whereas,Villa (2017) claimed that good cosmetic products are environmentally friendly, or "green cosmetics", with the use of solvent-free procedures with microwave irradiation, as a very useful and innovative methodology. Muslim women show interest that good quality cosmetic products are halal (Sugibayashi et al., 2019), cosmetic ingredients derived from plants, soil, water, animals permitted under Islamic law, marine animals are considered halal, and safe synthetic materials for consumers and not polluted with impurities (unclean). However, Sugibayashi et al. (2019) also found the fact that the association of halal cosmetics and the assessment of the performance of their products is still in its infancy.

Product quality is indicated to influence consumers in purchasing decisions for cosmetic products ((Hussin et al. (2013); Majid et al. (20I5); Lutfie et al. (2016)). More detailed, also discussed the effect of product quality on brand image (Lutfie et al. 2016), product quality and brand image on purchasing decisions(Roisah \& Riana, 2016).

$\mathrm{H}_{3}$ : There is a direct influence of product quality on brand image

$\mathrm{H}_{4}$ : There is a direct influence of product quality on purchasing decisions 


\section{Brand Image}

A brand in the market influences a company's ability to evaluate facts about how consumers interpret brand image, manage brand promotion strategies, and express brand equity adequately to consumers (Mohammadzadeh, 2015). Brand image is the customer's perception of the product or the overall impression of the product formed in their minds (Eze et al., 2012). Cahyani, Lapian, \& Tumiwa (20I5) explained that brand image influences purchasing decisions, supporting the findings of SallamSallam (20I4) andAlamanda, Aprillia, \& Prasetio (20I5). Aspan, Sipayung, Muharrami, \& Ritonga (2017) produced the same findings in halal cosmetic products.

$\mathrm{H}_{5}$ : There is a direct influence of brand image on purchasing decisions

According to the problem formulation, the conceptual framework proposed in this study is based on the literature review above presented in Figure I.

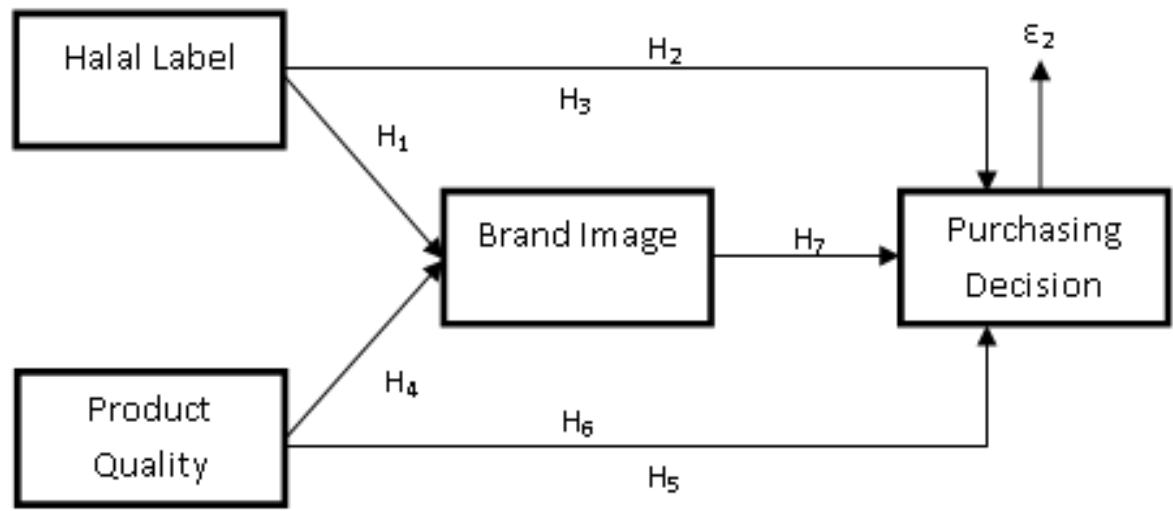

Figure I.Conceptual Framework

\section{METHODOLOGY}

\section{Research Design}

This research uses a quantitative method with a verification approach. The survey method was carried out by observing and distributing questionnaires to 400 respondents who used halal cosmetics with various brands in Indonesia. The questionnaire distribution technique was carried out using an online survey and purposive sampling method by following the Halal cosmetics Instagram account and looking for citizens who commented that they were cosmetic customers.

The data is processed using SPSS software for further analysis regarding the relationship between variables. The path analysis method is used to help answer the direct and indirect effects of the variables tested. The 4 variables in this study include halal labels, product quality, brand image, and purchasing decisions. The operationalization of this research variable is presented in Table I. 
Table I.Operationalization of Research Variables

\begin{tabular}{|c|c|}
\hline Dimensions & Indicators \\
\hline \multirow{2}{*}{$\begin{array}{l}\text { Consumer attention to the existence } \\
\text { of halal labels }\end{array}$} & Understanding of the existence of a logo \\
\hline & Understanding of halal labels \\
\hline $\begin{array}{l}\text { Halal label placement on the } \\
\text { packaging }\end{array}$ & The existence of halal labels \\
\hline \multirow{2}{*}{$\begin{array}{l}\text { Certainty that the product is safe to } \\
\text { use }\end{array}$} & Halal label in identifying halal products \\
\hline & Halal label as a consideration in purchasing \\
\hline Guaranteed safety for consumers & Consumer confidence \\
\hline Performance & Usage effect \\
\hline Reliability & Fulfillment of standards \\
\hline Suitability & Compliance with customer expectations \\
\hline Endurance & Packaging that is not easily damaged \\
\hline Ease of service & Ease of submitting complaints \\
\hline \multirow[t]{2}{*}{ Aesthetics } & Product texture \\
\hline & Product packaging \\
\hline Impression of quality & Product reputation \\
\hline \multicolumn{2}{|r|}{ Brand Image $(\mathrm{Y})$} \\
\hline Brand Strength & The logo is identical to the product \\
\hline \multirow[t]{3}{*}{ Brand Excellence } & Product halalness \\
\hline & Product quality \\
\hline & An affordable price \\
\hline \multirow[t]{4}{*}{ Brand uniqueness } & Product availability in the market \\
\hline & Brand that is easy to pronounce \\
\hline & Brands are easy to remember \\
\hline & Provide its own value in the minds of consumers \\
\hline \multicolumn{2}{|c|}{ Purchasing Decision $(\mathrm{Z})$} \\
\hline \multirow[t]{2}{*}{ Introduction to the problem } & The need for products \\
\hline & The desire for products \\
\hline \multirow[t]{2}{*}{ Information search } & Information based on personal experience \\
\hline & Information based on observations in the field \\
\hline \multirow[t]{2}{*}{ Alternative evaluation } & Price considerations \\
\hline & Assess some products \\
\hline \multirow[t]{3}{*}{ Purchasing decision } & Consumer attitudes when purchasing \\
\hline & Provisions in buying \\
\hline & Product satisfaction \\
\hline Post-purchase behavior & Repurchase \\
\hline
\end{tabular}

The hypothesis testing criteria are: if the Significance value $<\alpha(0.05)$, then both variables have a significant effect and $\mathrm{HO}$ is rejected, otherwise if the Significance value $>\alpha(0.05)$ then $\mathrm{HO}$ is accepted and $\mathrm{HI}$ is rejected.

\section{Profile of Respondents}

Respondents in this study are young women in Indonesia who use cosmetics. Some of the respondents who participated in filling out the 
questionnaire were from Garut Regency (25\%), Bondowoso Regency (25\%), Karangasem Regency (25\%) and East Lampung Regency (25\%). Based on the cosmetic brands used, of the 48 cosmetic brands there are 5 (five) most used cosmetic brands namely Wardah (31.80\%), Purbasari (7.53\%), Maybelline (5.86\%), Emina (4, 60\%), and Pixy (4.18\%). Based on the type of cosmetics, of the II types of cosmetics there are 5 (five) types of cosmetics most widely used by respondents, namely powder (40.53\%), lipstick (27.37\%), mascara (10.53\%), blush (6, 84\%), and eyeliner (5.79\%). Furthermore, based on cosmetics type of skin care, of the 16 types of skin care, there are 5 (five) types of cosmetics most used by respondents, namely facial wash $(35.90 \%)$, masks $(22.44 \%)$, moisturizers $(20.51 \%)$, toner $(5.13 \%)$, and sunscreen $(4.49 \%)$. In addition, the cosmetic brands that respondents use are dominated by local brands. The majority of respondents have used their cosmetics brand for 3-4 years.

\section{RESULT AND DISCUSSION}

Some of the steps carried out in the analysis include making a causal scheme or model between variables and determining an association pattern between the variables that have been presented in Figure I. The next step is to draw a path diagram, which is to facilitate path analysis, divided into 2 sub structure models .Explanation of each sub-structure of the model includes information about the relationships between variables, calculation of path coefficients, the results of the model compatibility test, and interpretation of results.

\section{Sub Structure of Model I (XI and X2 on Y)}

The results of processing using SPSS show that the R Square in the substructure of model $\mathrm{I}$ is 0.239 , where the brand image can be explained by the halal label and product quality by $23.9 \%$. Based on the results of the F test on the analysis of variance (ANOVA) shows that Model I is fit with the Sig. $(0,000)$ $<\alpha(0.05)$. Information about the path coefficient for sub-structure of model $\mathrm{I}$ is presented in Table 2.

Table 2. Path Coefficient Value in Sub Structure of Model I

\begin{tabular}{|c|c|c|c|c|c|}
\hline \multirow[b]{2}{*}{ Model } & \multicolumn{2}{|c|}{ Unstandardized Coefficients } & \multirow{2}{*}{$\begin{array}{c}\begin{array}{c}\text { Standardized } \\
\text { Coefficients }\end{array} \\
\text { Beta } \\
\end{array}$} & \multirow[b]{2}{*}{$t$} & \multirow[b]{2}{*}{ Sig. } \\
\hline & $\mathrm{B}$ & Std. Error & & & \\
\hline I (Constant) & II,339 & 2,560 & & 4,429 & ,000 \\
\hline Halal Label & ,308 & , I05 & ,273 & 2,938 & ,004 \\
\hline Product Quality & ,32I & ,09I & ,330 & 3,543 & ,00I \\
\hline
\end{tabular}


Halal label path coefficient on brand image is 0.273 and significance value $(0.004)<\alpha(0.05)$, which indicates that halal label has a significant effect on brand image by 0.273 or $27.3 \%$. Meanwhile, the product quality path coefficient on brand image is 0.330 and the significance value $(0.00 \mathrm{I})<\alpha(0.05)$, which indicates that product quality partially significantly influences brand image by 0.330 or $33 \%$. The results of the sub structure of model I are presented in Figure 2.

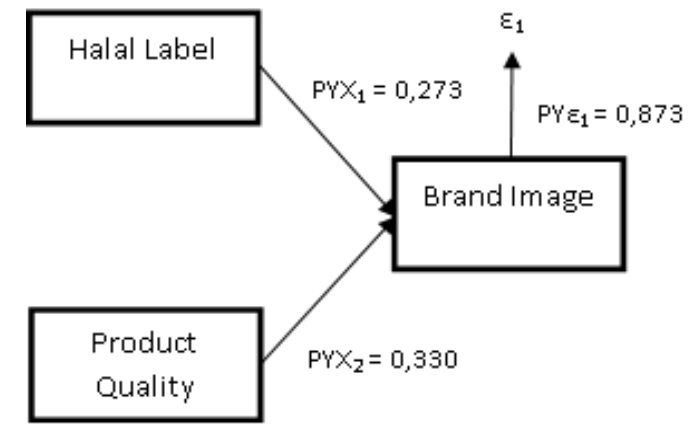

Figure 2. Sub structur of model I

The empirical causal influence of halal labels and product quality on brand image can be stated in the equation:

$\mathrm{Y}=\rho \mathrm{YX}_{\mathrm{I}}+\rho \mathrm{YX}_{2}+\rho \mathrm{Y} \varepsilon_{1}$ atau $\mathrm{Y}=0,273 \mathrm{YX}_{\mathrm{I}}+0,330 \mathrm{YX} \mathrm{X}_{2}+0,873 \varepsilon_{\mathrm{I}}$.

Based on the partial test on sub-structure of model I, the value of all variables shows significance $<\alpha(0.05)$, it can be concluded that:

I) $\mathrm{HI}$ is rejected, meaning that the halal label (XI) influences the brand image (Y);

2) H3 is rejected, meaning that product quality (X2) influences brand image (Y).

\section{Sub Structure of Model 2 ( $\mathrm{X}_{\mathrm{I}}, \mathrm{X}_{2}$ and $\mathrm{Y}$ on $\left.\mathrm{Z}\right)$}

$\mathrm{R}$ Square produced in the sub-structure of model 2 is 0.479 , meaning that the purchase decision variable can be explained by the halal label variable, product quality and brand image by $47.9 \%$.

Based on the results of the $\mathrm{F}$ test on the analysis of variance (ANOVA), Model 2 is fit with the Sig. $(0,000)<\alpha(0.05)$. Table 3 shows information about the path coefficient for the sub-structure of model 2 . 
Table 3. Path Coefficient Value in Sub Structure of Model 2

\begin{tabular}{|c|c|c|c|c|c|}
\hline \multirow[b]{2}{*}{ Model } & \multicolumn{2}{|c|}{ Unstandardized Coefficients } & \multirow{2}{*}{$\begin{array}{c}\text { Standardized } \\
\text { Coefficients } \\
\text { Beta }\end{array}$} & \multirow[b]{2}{*}{$\mathrm{t}$} & \multirow[b]{2}{*}{ Sig. } \\
\hline & B & Std. Error & & & \\
\hline (Constant) & 4.735 & $4.49 \mathrm{I}$ & & $\mathrm{I} .054$ & .294 \\
\hline Label Halal & .962 & .175 & .444 & 5.495 & .000 \\
\hline KualitasProduk & .280 & .154 & .150 & $\mathrm{I} .82 \mathrm{I}$ & .072 \\
\hline Citra Merek & .560 & .162 & .291 & 3.449 & .001 \\
\hline
\end{tabular}

Halal label path coefficient on purchasing decisions of 0.444 , meaning that partially halal labels significantly influence purchasing decisions of 0.444 or $44.4 \%$. While the product quality to the purchase decision obtained significance value $(0.072)<\alpha(0.05)$ and path coefficient of 0.150 , meaning that partially the product quality does not significantly influence the purchase decision. Furthermore, the brand image of the purchase decision, the path coefficient value of $0.29 \mathrm{I}$, meaning that partially the brand image significantly influences the purchase decision of $0.29 \mathrm{I}$ or $29.1 \%$. The results of the sub structure of model 2 are presented in Figure 3.

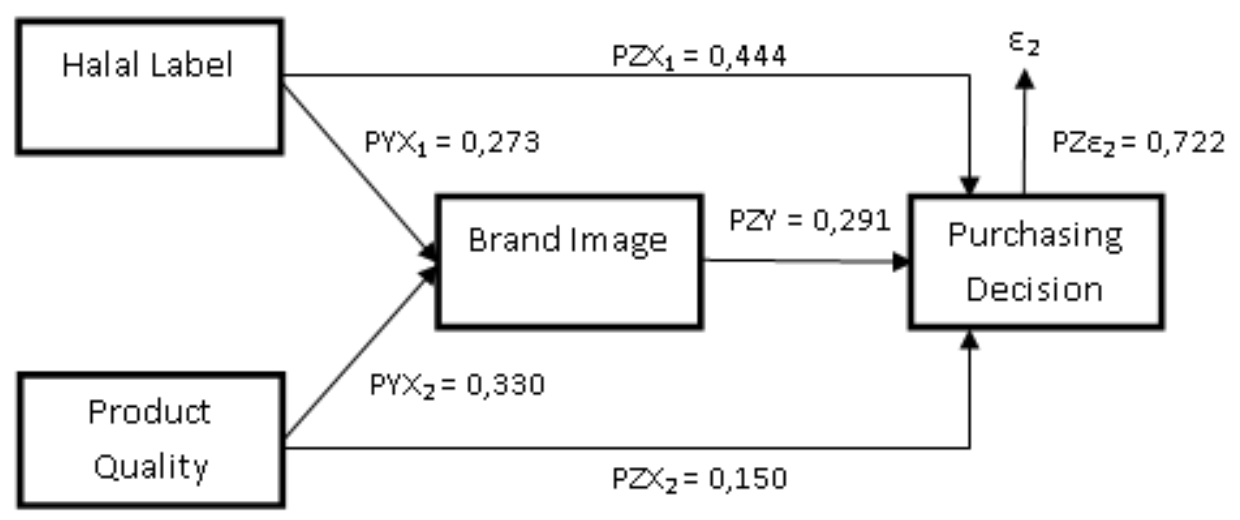

Figure 3. Sub structur of model 2

The empirical influence of halal label and product quality on brand image can be expressed in the equation $Z=\rho Z X I+\rho Z X 2+\rho Z Y+\rho Y \varepsilon 2$ or $Y=$ $0,444 Z X I+0,150 Z X 2+0,29 \mathrm{IZY}+0,722 \varepsilon 2$. The indirect effects based on the above model are as follows:

I) The indirect effect of halal labels on purchasing decisions through brand image:

$\mathrm{Z} \quad=\rho Y \mathrm{X}_{\mathrm{I}} \times \rho \mathrm{YZ}$ 


$$
\begin{aligned}
& =0,273 \times 0,29 I \\
& =0,079
\end{aligned}
$$

2) The indirect effect of product quality on purchasing decisions through brand image:

$$
\begin{aligned}
\mathrm{Z} & =\rho \mathrm{YX}_{2} \times \rho \mathrm{YZ} \\
& =0,330 \times 0,29 \mathrm{I} \\
& =0,096
\end{aligned}
$$

Based on Table 3 , the coefficient on the halal label variable obtained a significance value of 0,000 , the product quality variable obtained a significance value of 0.072 , while the brand image variable obtained a significance value of 0.00I. Based on the results of the partial test on sub-structure of model 2 , it can be concluded that:

a) $\mathrm{H} 2$ is rejected, meaning that the halal label (XI) influences the purchase decision $(Z)$;

b) H4 is accepted, meaning that product quality (X2) has no effect on purchasing decisions $(\mathrm{Z})$;

c) H5 is rejected, meaning that the brand image $(Y)$ influences the purchase decision $(Z)$.

\begin{tabular}{|c|c|c|c|}
\hline Findings & $\begin{array}{l}\text { Decision of } \\
\text { Findings I }\end{array}$ & $\begin{array}{l}\text { Decision of } \\
\text { Findings } 2\end{array}$ & Information \\
\hline $\begin{array}{l}\text { Halal label (XI) influences brand } \\
\text { image }(Y)\end{array}$ & Hi Rejected & Hi Rejected & supported \\
\hline $\begin{array}{l}\text { Halal label }(\mathrm{XI}) \\
\text { purchasing decisions }(\mathrm{Z})\end{array}$ & $\mathrm{H}_{2}$ Accepted & $\mathrm{H}_{2}$ Rejected & Not supported \\
\hline $\begin{array}{l}\text { Product quality (X2) influences } \\
\text { brand image }(\mathrm{Y})\end{array}$ & $\mathrm{H}_{3}$ Accepted & $\mathrm{H}_{2}$ Rejected & Not supported \\
\hline $\begin{array}{l}\text { Product quality (X2) influences } \\
\text { purchasing decisions (Z) }\end{array}$ & $\mathrm{H}_{4}$ Accepted & $\mathrm{H}_{4}$ Accepted & supported \\
\hline $\begin{array}{l}\text { Brand image }(\mathrm{Y}) \\
\text { purchasing decisions }(\mathrm{Z})\end{array}$ & $\mathrm{H}_{5}$ Rejected & $\mathrm{H}_{5}$ Rejected & supported \\
\hline
\end{tabular}

Research using the same conceptual framework has been conducted byLutfie et al. (2016). A comparison of previous findings with this study is presented in Table 4.

Table 4.Comparison of Findings I and Findings 2

From Table 4, it can be seen that from the five hypotheses proposed, 3 hypotheses are consistent with previous findings, and 2 hypotheses have changed results. Supporting findings include that halal labels influences brand image; product quality influences purchasing decisions; and brand image (Y) influences purchasing decisions. Whereas, 2 different findings were that the halal label had 
an influence on purchasing decisions and the product quality had an influence on the brand image.

The difference in findings can occur due to many factors, the first study population being young women in urban areas, while the second study population was young women in rural areas. If the population is different, surely the sample is also different (Faber \& Fonseca, 20I4). In urban populations, the halal label has no influence on purchasing decisions, meaning that young women have a low level of halal awareness. Rahim, Shafii, \& Shahwan (2015) stated that although halal has become the lifestyle of Muslim consumers in the world. However, awareness of the halal food sector has not significantly impacted halal awareness in cosmetics. Whereas in rural Indonesia, religious values are still very dominant in society, so that halal awareness is better than urban populations.

Another different finding is, in urban populations, product quality does not affect the brand image of a product. That could be because young women in urban areas are more critical than those in rural areas, product quality is only a small part that affects the brand image of cosmetic products, other issues such as endorsers, environmental issues, and organic raw materials are factors that have a greater influence on brand image.

Based on findings that support previous studies where the halal label influences the brand image of cosmetics, it means that cosmetic products that have a halal label on the packaging are able to build the image that the product is a halal product. Then, there is no doubt that brand image influences purchasing decisions.

An interesting finding from this study is that both findings agree that product quality has no effect on cosmetics purchases. These results can occur because of the price factor is still a major consideration or the behavior of Indonesian women who like to try various cosmetic brands only because of impulse buying or because of curiosity. Thus, satisfying product quality is not enough to make consumers loyal to a product.

\section{E. CONCLUSION}

Increased awareness of people related to halal labels and product quality affects their decision to buy products and services in all industrial sectors including the cosmetics industry, whose market is dominated by women. Based on previous research showed that the halal label is able to improve the brand image of the industry (Lutfie, Suzanti, Omar Sharif, \& Alamanda, 2016), but cannot influence purchasing decisions. This study considers that purchasing decisions are influenced by brand image, where halal labels and product quality are the factors 
that shape a brand image. From the test results it can be concluded that the halal label influences the brand image; Halal labels also influence purchasing decisions. Not only halal labels, product quality also affects the brand image but does not affect the purchase decision. Furthermore, brand image influences purchasing decisions.

\section{Recommendations}

This study is in line with the study of Sugibayashi et al, (2019) who suggested that the need for the development of halal cosmetics that includes the concept of critical sources of halal ingredients, applies halal practices in every step of the manufacturing process, and ensures the compatibility of product performance with Islamic law. Although the awareness of halal cosmetics in cities and villages is different, the similarity is that they still need better direction and support from practitioners of religion, government, academics, community and media.

\section{REFERENCES}

Adinugraha, H. H., \& Sartika, M. (2019). Halal lifestyle di indonesia. AnNisbah: Jurnal Ekonomi Syariah. https://doi.org/I0.2I274/an.2019.5.2.

Aisyah, M. (2016). Consumer Demand on Halal Cosmetics and Personal Care Products in Indonesia. Al-Iqtishad: Journal of Islamic Economics. https://doi.org/IO.I5408/aiq.v9iI.I867

Alamanda, D. T., Aprillia, D., \& Prasetio, A. P. (2015). The Effect of the New Logo and Brand Image Towards the Customer Loyalty of Starbuck, Jakarta. 2 Nd International Conference on Innovation on Global Trends In Academic Research. Bandung: Global Illuminators Publishing.

Aspan, H., Sipayung, I. M., Muharrami, A. P., \& Ritonga, H. M. (2017). The Effect of Halal Label, Halal Awarness, Product Price, and Brand Image to the Purchasing Decision on Cosmetic Products (Case Study on Consumers of Sari Ayu Martha Tilaar in Binjai City). International Journal of Global Sustainability. https://doi.org/I0.5296/ijgs.vIiI.I20I7

Briliana, V., \& Noviana, R. (2016). The antecedents and outcome of halal cosmetic products: a case study in jakarta indonesia. International Journal of Business, Economics and Law.

Cahyani, N. S., Lapian, S. L. H. V. J., \& Tumiwa, J. (2015). The effect of brand image, perceived price, and perceived quality on consumers' purchase decision of pond's skin care product. Jurnal EMBA, 5(2), 354-362.

Endah, N. H. (20I4). Consumers's purchasing behavior toward halal labeled 
IKONOMIKA

Volume 4, No 2(2019)

cosmetics in indonesia. Jurnal Ekonomi Dan Pembangunan. https://doi.org/I0.I4203/JEP.22.I.20I4.25-39

Eze, U. C., Tan, C.-B., \& Yeo, A. L.-Y. (2012). Purchasing Cosmetic Products: A Preliminary Perspective of Gen-Y. Contemporary Management Research. https://doi.org/I0.7903/cmr.I0I49

Faber, J., \& Fonseca, L. M. (20I4). How sample size influences research outcomes. Dental Press Journal of Orthodontics. https://doi.org/I0.I590/2I76-945I.19.4.027-029.ebo

Hamzah, H., Ayodahya, D. T., \& Haque, M. S. (2019). The Effect of Halal Certificate towards Chicken Meat Import between Brazil and Indonesia according to Rule of GATT-WTO. IKONOMIKA, 4(2), I7I-I80.

Hanzaee, K. H., \& Ramezani, M. R. (20I I). Intention to Halal Products In THe World Markets. Interdisciplinary Journal of Research in Business.

Hasibuan, H. A., Dharma, M., Putra, T., \& Anggraini, F. (2017). The Effect of Halal Label, Halal Awareness and Brand Image on Consumer Intention to Buy. International Journal for Innovative Research in Multidisciplinary.

Hussin, S. R., Hashim, H., Yusof, R. N., \& Alias, N. N. (2013). Relationship between product factors, advertising, and purchase intention of Halal cosmetic. Pertanika Journal of Social Science and Humanities.

Islam, T., \& Chandrasekaran, D. U. (2013). Halal Marketing: Growing The Pie. International Journal of Management Research and Review.

Joelle, R. M., . S., \& Hermawan, A. (2017). Analysis of Women Consumer Behavior for Purchasing Oriflame Cosmetic Product: Phenomenology. International Journal of Academic Research in Business and Social Sciences. https://doi.org/I0.6007/ijarbss/v7-i6/3047

Khan, A., Karim, E., \& Abbas, O. (20I6). Identifying the Factors affecting the customer's Buying Behavior: A case study of Men's cosmetic Market in Karachi, Pakistan. Journal of Business Strategies.

Kumar, H. H., John, S. F., \& Senith, S. (2014a). A Study on factors influencing consumer buying behavior in cosmetic Products. International Journal of Scientific and Research Publications, 4(I), 2250-3153. Retrieved from www.ijsrp.org

Kumar, H. H., John, S. F., \& Senith, S. (20I4b). A Study on factors influencing consumer buying behavior in cosmetic Products. International Journal of Scientific and Research Publications.

Lutfie, H., Suzanti, E. P. P., Omar Sharif, O., \& Alamanda, D. T. (2016). Which is More Important? Halal Label or Product Quality. https://doi.org/I0.299I/isclo-I5.2016.4I 
Majid, M. B., Sabir, I., \& Ashraf, T. (2015). Consumer Purchase Intention towards Halal Cosmetics \& Personal Care Products in Pakistan. Global of Research in Business \& Management.

MarkPlusinc. (2016). Halal and Herbal - the two emerging buzzwords in Indonesia's cosmetics market.

Mohammadzadeh, R. (2015). The Effect of Brand Image and Purchase Intention on Cosmetic Products: Evidence from North Cyprus (Eastern Mediterranean University). Retrieved from http://hdl.handle.net/I I I29/367 I

Mohezar, S., Zailani, S., \& Zainuddin, Z. (2016). Halal cosmetics adoption among young Muslim consumers in Malaysia: Religiosity concern. Global Journal Al-Thaqafah. https://doi.org/I0.7I87/GJATI022016060I

Noor, F. A. (2015). Popular religiosity in Indonesia today: The next step after "Islam Kultural"? Al-Jami’ah. https://doi.org/IO.I442I/ajis.20I5.532.283-302

Nusran, M., Gunawan, Razak, M., Numba, S., \& Wekke, I. S. (2018). Halal Awareness on the Socialization of Halal Certification. IOP Conference Series: Earth and Environmental Science. https://doi.org/I0.I088/I755I3I5/I75/I/0I22I7

Putri, I. S., Daryanti, S., \& Ningtias, A. R. (2019). The Influence of Knowledge and Religiosity with Mediation of Attitude Toward the Intention of Repurchasing Halal Cosmetics. https://doi.org/10.2991/icbmrI8.2019.29

Putri, T. U., \& Abdinagoro, S. B. (2018). Response to a New Wave in Digital marketing: Does beauty blogger involvement the most influencing factor in halal cosmetic purchase intention. International Journal of Supply Chain Management.

Rahim, N. @ F. binti, Shafii, Z., \& Shahwan, S. (2015). Awareness and Perception of Muslim Consumers on Halal Cosmetics and Personal Care Products. International Journal of Business, Economics and Management. https://doi.org/IO.I8488/journal.62/20I5.2.I/62.I.I.I4

Rajagopal, S., Ramanan, S., Visvanathan, R., \& Satapathy, S. (20II). Halal certification: Implication for marketers in UAE. Journal of Islamic Marketing. https://doi.org/IO.I I08/I759083 I I I I I39857

Rauschnabel, P. A., Herz, M., Schlegelmilch, B. B., \& Ivens, B. S. (20I5). Brands and religious labels: a spillover perspective. Journal of Marketing Management. https://doi.org/I0.I080/0267257X.20I5.I0I3489

Roisah, R., \& Riana, D. (2016). Telaah Hubungan Citra Merek, Kualitas Produk Dan Keputusan Pembelian Konsumen. Jurnal Ecodemica: Jurnal Ekonomi, 
Manajemen, Dan Bisnis. https://doi.org/I0.3I3I I/JECO.V4II.35I

Sa'id, D. P. dan E. G. (20I2). ASEAN Halal Agro-Industry Product Institutional Competitiveness Mapping. Internasional Conference Food Science and Nutrition.

Sallam, M. A. (20I4). The Effects of Brand Image and Brand Identification on Brand Love and Purchase Decision Making: The Role of WOM. International Business Research. https://doi.org/I0.5539/ibr.v7nIOpI87

Salvador, A., \& Chisvert, A. (2007). Analysis of Cosmetic Products. In Analysis of Cosmetic Products. https://doi.org/I0.I0I6/B978-0-444-522603.X5020-7

Sugibayashi, K., Yusuf, E., Todo, H., Dahlizar, S., Sakdiset, P., Arce, F. J., \& See, G. L. (2019). Halal cosmetics: A review on ingredients, production, and testing methods. Cosmetics. https://doi.org/I0.3390/cosmetics6030037

Villa, C. (2017). Green Cosmetic Ingredients and Processes. In Analysis of Cosmetic Products: Second Edition. https://doi.org/I0.I016/B978-0444-63508-2.000I3-8

Vinardell, M. P., \& Mitjans, M. (2017). Alternative methods to animal testing for the safety evaluation of cosmetic ingredients: An overview. Cosmetics. https://doi.org/I0.3390/cosmetics4030030

Yuswati, M. (2018). Indonesian SPA asSharia Tourism Education Opportunity. https://doi.org/I0.299I/amca-I8.2018.16I

Zhang, J., \& Zhou, M. (2019). Factors Influencing Consumer Purchasing Behavior of Natural Cosmetics. Uppsala University. 
Halal Label vs Product Quality in Halal Cosmetic Purchasing Decisions

Grisna Anggadwita ${ }^{1}$, DiniTuripanam Alamanda ${ }^{2}$, and Veland Ramadani ${ }^{3}$

https://ejournal.radenintan.ac.id/index.php/ikonomika 